\title{
IMPACT OF DIFFERENT COMBINATIONS OF INHALED CORTICOSTEROIDS AND LONG-ACTING SYMPATHICOMIMETICS ON DENTAL HEALTH OF ASTHMATICS
}

\author{
Emilia Karova ${ }^{1}$, George Christoff ${ }^{2}$ \\ 1) Department of Conservative Dentistry, Faculty of Dental Medicine, \\ 2) Department of Health Economics, Faculty of Public Health, \\ Medical University, Sofia, Bulgaria
}

\section{SUMMARY:}

The aim of the investigation is to study the effect of inhaled corticosteroids and long-acting sympathicomimetics on dental health in asthmatics.

Thirty patients, from 20 to 55 years old, participate in the study. D-, M-, F- and DMFT indexes are determined in a 6 months period. All participants fill in a questionnaire.

Asthmatics complain most frequently from oral dryness, take frequently sugar and soft drinks and visit irregularly dental practitioners. A significant increase in Mindex is found out at the second visit. F-index increases considerably for patients treated with Beclometasone and Formoterol and D-index decreases significantly when treated with Budesonide and Formoterol. DMFT index increases considerably for all patients. Highest values of DMFT index are registered for patients treated with Fluticasone propionate and Salmeterol.

Prolonged use of inhaled drugs with greater quantities of lactose leads to more impaired dental status in asthmatics and higher values of DMFT index.

Key words: asthma, inhaled corticosteroids, inhaled long-acting sympathicomimetics, oral dryness, dental status

\section{INTRODUCTION:}

Combinations of inhaled corticosteroids and longacting sympathicomimetics are up-to-date treatment of bronchial asthma. Some of them are in aerosol form (MDI), others - in powder form (DPI). DPI are devices containing gustatory correctors in different quantities (Fluticasone propionate + Salmeterol $-12.5 \mathrm{mg}$ Lactose monohydrate, Budesonide + Formoterol - 0.730 mg Lactose monohydrate, Beclometasone + Formoterol - without correctors). The inhaled drugs can reduce substantially salivary quantity and $\mathrm{pH}$, break oral homeostasis and increase caries risk because of their composition.[13]

Oral environment can be changed not only under the influence of inhaled drugs but of other external factors, such as intake of sugar, sugar substances and non-alcoholic drinks, etc. $[14,15,17,26,44,46]$

Dental caries is a chronic disease involving localized destruction of specific sites of tooth surface. It is a multifactorial dynamic process that is modified by protective factors. [7, 8, 17, 25, 45, 46]

Very often appearance of dental caries is associated with frequency of sugar intake. Sucrose is the most important representative of this group, followed by glucose, fructose and lactose. Sucrose freely diffuses in dental plaque and is easily metabolized by oral bacteria. Organic acids concentration increases to levels that can lower plaque $\mathrm{pH}$ to a degree adequate for demineralization of tooth enamel. $[9,11,12,14$, $15,17,20,22-26,36,44-46]$

There is little evidence in literature for the relation between dental health in asthmatics and their treatment. Most of the studies are carried out on kids and the obtained results are contradictory. $[5,6,13,18,21,27,35,41,42,47]$

\section{MATERIAL AND METHODS:}

Thirty asthmatics of both sexes, from 20 to 55 years old, participate in the study. They suffer from mild persistent asthma and are systematically treated with combinations of inhaled corticosteroids and long-acting sympathicomimetics. All patients with accompanying diseases and treatment, affecting saliva quantity and oral acidity are excluded from the investigation. Those with bad oral hygiene and parodontal diseases are excluded as well.

The asthmatic patients are divided in three groups, according to their medication: Seretide - Fluticasone propionate + Salmeterol, Symbicort - Budesonide + Formoterol and Foster- Beclometasone + Formoterol. The active component in all devices is inhaled in a dry powder form. The investigated medications have different quantities of gustatory correctors - $12,5 \mathrm{mg}$ Lactose monohydrate in Fluticasone propionate + Salmeterol; $0.730 \mathrm{mg}$ Lactose monohydrate in Budesonide + Formoterol and no correctors in Beclometasone + Formoterol. 
All participants fill in a questionnaire, giving information about their dietary habits, frequency of visits to dental practitioners and complaints from oral cavity.

Decayed, missing and filled teeth are determined with the help of D-, M-, F- and DMFT indexes (after the standards of WHO). Loss of teeth because of trauma and orthodontic reasons are not counted.

Changes in dental status are evaluated in two visits, in six months interval.

Data analyses are conducted using statistical software program SPSS 15.0.

\section{RESULTS:}

All patients have given their subjective evaluation of the presence of oral and eye dryness, burning mouth, tooth pains and high dental sensitivity.

Asthmatics complain most frequently from oral dryness (70\%), eye dryness (30\%) and high dental sensitivity $(23.3 \%)$.

Frequency of sugar intake is traced out in the following groups: never take, once a week or less, 2-6 times a week, 1-2 times daily and more than twice daily.

According to the given answers in the questionnaire, we find out a frequent intake of sugar products in asthmatics $-33.3 \%$ take them $2-6$ times a week and $33.3 \%-1-2$ times daily.

Drinking of soft drinks is estimated in the following groups: never drink, once a week or less, 2-6 times a week, 1-2 times daily and more than twice daily.
We discover frequent intake of soft drinks $-50 \%$ of the asthmatics consume them frequently (1-2 times daily or more). Only a quarter of the patients drink soft drinks less than once a week.

All patients are questioned about the frequency of their visits at the dentist's. The following groups are formed: never visit, only in emergency, irregularly, regularly once a year.

The percentage of asthmatics who irregularly visit their dentists predominates $-60 \%$ look for dental aid only in emergency or irregularly. Regular visits are found out only in $40 \%$ of the patients.

D-, M- and F- indexes are calculated for each group of asthmatics in their both visits. Highest average values of $\mathrm{D}$ - and F- indexes at the second visit are found out in patients treated with Fluticasone propionate and Salmeterol (Seretide) - respectively 5.4 and 13.0. Only in the same group we determine an increase in the number of decayed teeth when compared with the initial status - from 4.9 to 5.4. In the groups of asthmatics treated with Budesonide and Formoterol (Symbicort) and Beclometasone and Formoterol (Foster) number of filled and extracted teeth increase.

The comparison between the indexes values at both visits shows a significant increase in $\mathrm{M}$-index for all groups (paired simple t-test, $\mathrm{p}<0,05$ ). Values of F-index increase considerably in the group of patients treated with Beclometasone and Formoterol (Foster) (paired simple t-test, $\mathrm{p}=0,045)$ and these treated with Budesonide and Formoterol (Symbicort) have significantly lower values of D-index (paired simple t-test, $\mathrm{p}=0,046)$. Table 1 , Fig. 1

Table 1. Dental status of asthmatics in accordance of their treatment

\begin{tabular}{|l|l|l|l|l|l|l|l|l|l|l|l|l|}
\hline & \multicolumn{4}{|c|}{ Foster } & \multicolumn{4}{c|}{ Seretide } & \multicolumn{4}{c|}{ Symbicort } \\
\cline { 2 - 28 } & D & M & F & DMFT & D & M & F & DMFT & D & M & F & DMFT \\
\hline First visit & 5,7 & 0,9 & 9,9 & 16,5 & 4,9 & 1,1 & 13 & 19 & 6,4 & 1,6 & 10,7 & 18,7 \\
\hline Second visit & 4,5 & 1,7 & 11,2 & 17,4 & 5,4 & 2,5 & 13 & 20,9 & 4,2 & 2,8 & 12,6 & 19,6 \\
\hline
\end{tabular}

Fig. 1. Dental status of asthmatics in accordance of their treatment in a 6 months period

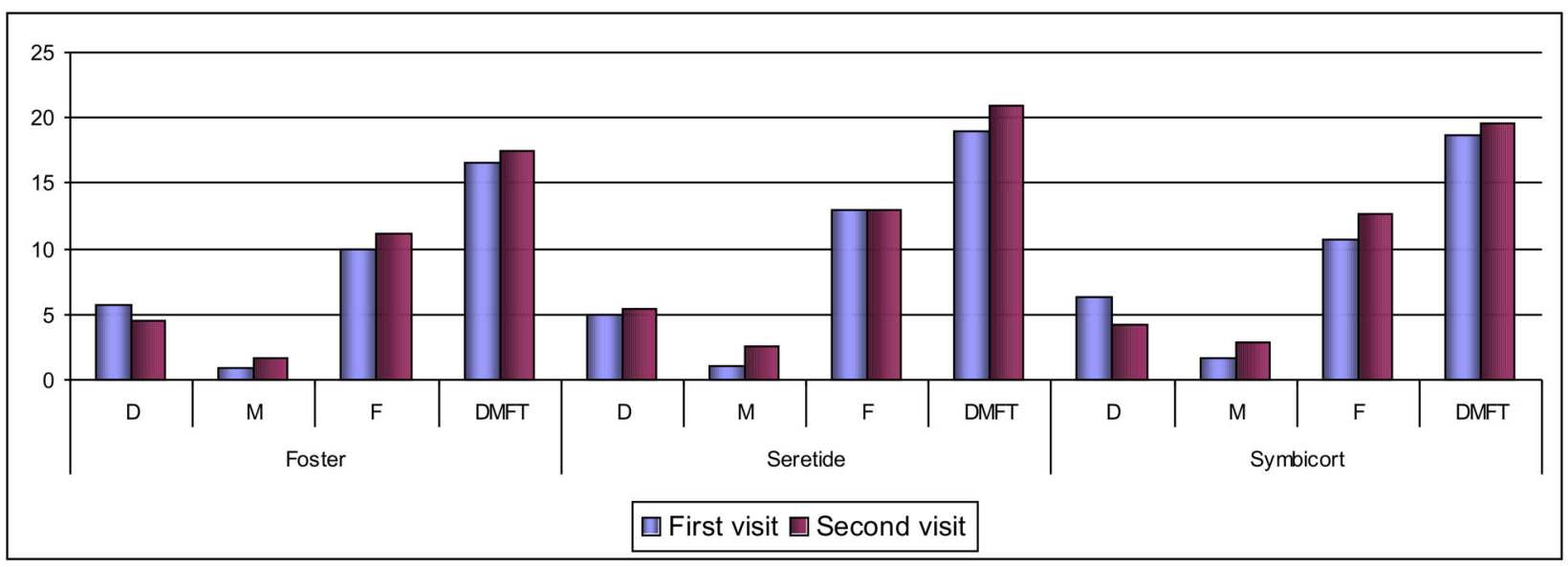


The average values of DMFT index increase considerably at the second visit of the patients from each examined group (paired simple t-test, $\mathrm{p}<0.05$ ).

At the first visit highest value of DMFT index is found out for the patients treated with Fluticasone propionate and Salmeterol (Seretide) - 19.0, followed by these treated with Budesonide and Formoterol (Symbicort) - 18.7 and Beclometasone and Formoterol (Foster) - 16.5. We find out higher values of DMFT index at the second visit of asthmatics, keeping the same arrangement - Fluticasone propionate and Salmeterol (Seretide) - 20.9, Budesonide and Formoterol (Symbicort) - 19.6 and Beclometasone and Formoterol (Foster) - 17.4. The differences between the groups at each visit are insignificant (first visit $-\mathrm{p}=0.523$, second visit $-\mathrm{p}=0.286$ ). Table 1, Fig. 2

Fig. 2. DMFT indexes in asthmatic groups at each visit

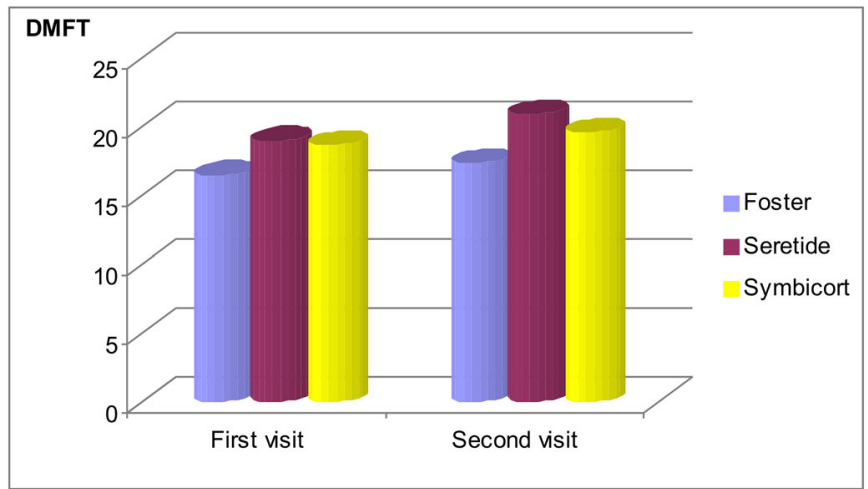

The average values of DMFT index for maxilla and mandible in each group are calculated. The same tendency of higher values at the control visit is revealed. But only in the group of asthmatics treated with Fluticasone propionate and Salmeterol (Seretide) we find out significant increase for upper and lower jaw (paired simple t-test, respectively $\mathrm{p}=0.037$ and $\mathrm{p}=0.007$ ). Fig. 3 and 4

Fig. 3 and 4. DMFT index for upper and lower jaw in each group in a 6 months period

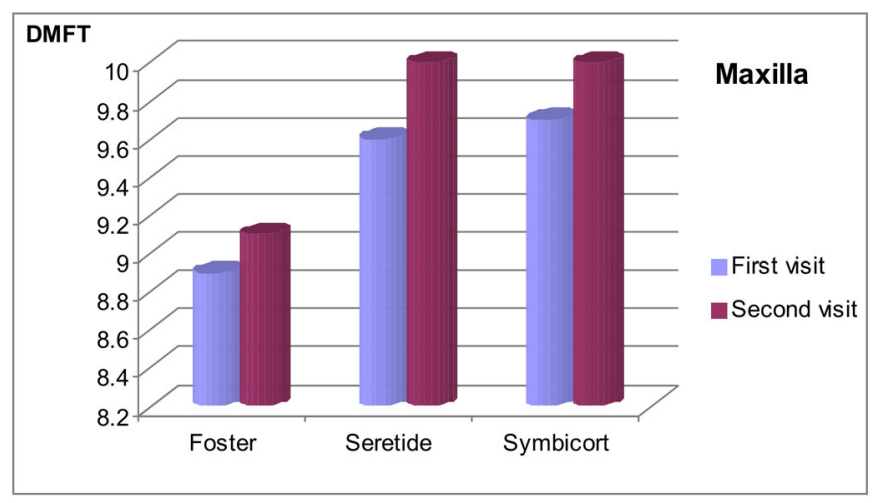

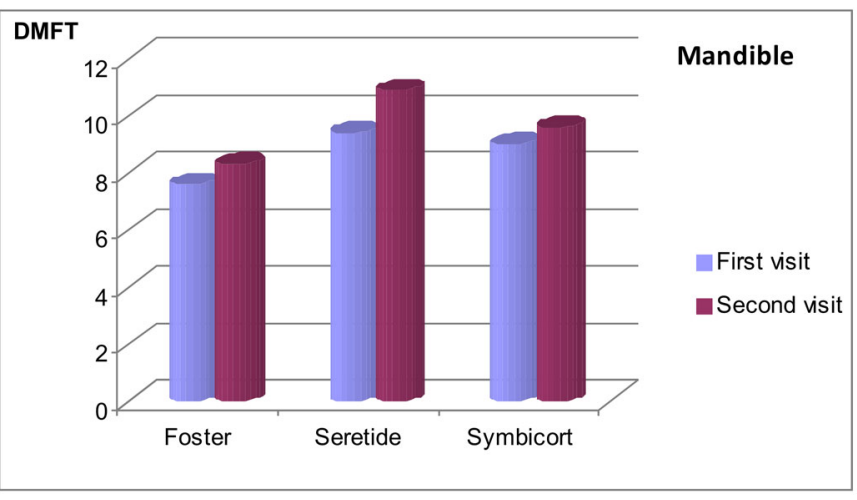

\section{DISCUSSION:}

Oral and eye dryness are the most frequent complaints of questioned asthmatics. We assume that the inhaled longacting sympathicomimetics decrease saliva quantity and cause the feeling of oral dryness. The effect of these drugs on saliva secretion is well examined in literature and it is found out that their prolonged use causes decrease of salivary quantity. $[4-6,10,21,28,33,37]$ The received results are expected and are identical with these of Ryberg et al. [31, 32] and Kargul et al. [19]. Confirmation about the influence of prescribed drugs and patients health status on saliva secretion and oral dryness can be found in other studies of patients, suffering from different chronic diseases.[1-3]

Conversely, Hyypa and Paunio examine asthmatic children and don't find a connection between prescribed treatment and saliva secretion and the feeling of oral dryness. [16]

The increased intake of sugar products and sweetened soft drinks creates an aggressive oral environment for hard dental tissues in asthmatics. The increased intake of soft drinks is expected by reason of decreased salivary quantity in these patients. The same results are obtained by the teams of McDerra [27] and M. Stensson [38-40]. On the contrary, P.Paunio et al. [30], Shulman J.D. et al. [35], Bjerkebornet al. [5] and K. Storhaug [41] do not find any changes in the consumption of soft drinks.

Maybe, the low percentage of regular visits at the dentist's is a result of a lack of motivation and information about the local effects of inhaled drugs, which asthmatics take for a long time. This can reflect negatively their dental status.

Comparing the effect of each inhaled drug upon dental status in asthmatics we tried to trace out the importance of their composition. The average values of DMFT index increase significantly at the second visit for each group. Although the differences are not significant, the highest values are registered for patients taking drugs with higher quantities of lactose, as gustatory correctors (Fluticasone propionate and Salmeterol- Seretide and Budesonide and Formoterol Symbicort). Significant differences in DMFT index for upper and lower jaws are registered only for patients treated with Fluticasone propionate and Salmetero (Seretide). The results 
are expected because these drugs contain higher quantities of lactose as gustatory corrector. They are expected to increase their harmful effect on hard dental tissues because of their everyday use for a long period of time.

The harmful effect of inhaled drugs on dental status is revealed in the studies of O'Sullivan E. et al. [29], Kankaala T. et al. [18] and Shashikiran N. [34].

Wogelius P.et al. [43] assume that caries risk is lower when only one drug is inhaled and is increased with the increase of the number of the inhaled drugs.

Comparison of dental status of upper and lower jaws can be found in the work of McDerra et al. [27] They state impaired dental status in asthmatics and more affected labial surfaces of upper incisors and occlusal surfaces of molars.

\section{CONCLUSIONS:}

- Asthmatics treated with inhaled corticosteroids and long-acting sympathicomimetics complain most frequently from oral dryness.

- Increased intake of sugar products and soft drinks and the irregular visits at the dentist's increase the caries risk for asthmatics.

- As a result of the prolonged treatment of bronchial asthma with inhaled corticosteroids and long-acting sympathicomimetics, DMFT index increases. Upper teeth are more affected than lower ones.

- Inhaled corticosteroids and long-acting sympathicomimetics with greater quantities of lactose have more harmful effect on dental status in asthmatics.

\section{REFERENCES:}

1. Dencheva-Garova M. Maxillofacial focuses in patients on haemodialisis and with renal transplantation clinical protocol, Dissertation, S., 2010 (in Bulgarian)

2. Panov VE. Oral cavity - biosystem and possible focus of infectious material, Dissertation, V., 2010 (in Bulgarian)

3. Anjomshoaa I, Cooper ME, Vieira AR. Caries is Associated with Asthma and Epilepsy. Eur J Dent. 2009 Oct;3(4):297-303. [PubMed]

4. Bergdah M, Bergdahl J. Low unstimulated salivary flow and subjective oral dryness: association with medication, anxiety, depression and stress. J Dent Res. 2000 Sep;79(9): 1652-1658. [PubMed] [CrossRef]

5. Bjerkeborn K, Dahllof G, Hedlin G, Lindell M, Modeer T. Effect of disease severity and pharmacotherapy of asthma on oral health in asthmatic children. Scand J Dent Res. 1987 Apr; 95(2):159-164. [PubMed]

6. Blume A, Viergutz G, Hetzer G. The Dental Health Status of Asthmatic german Children and Adolescents. Caries Res. 2001, 35:297/99 A

7. Bowen WH. Do we need to be concerned about dental caries in the coming millenium? Crit Rev Oral Biol Med. 2002 Mar;13(2):126-131. [PubMed] [CrossRef]

8. Bowen WH, Birkhed D. Dental caries Dietary and microbiology factors. In Granath L, McHugh WD, eds.
Systematized Prevention of Oral Disease: Theory and Practice. Boca Raton, FLa: CRC Press, 1986:19-41

9. Burt BA, Pai S. Sugar consumption and caries risk: a systematic review. J Dent Educ. 2001 Oct; 65(10):10171023. [PubMed]

10. Coxon M. Xerostomia: common causes of the condition. Dental Nursing. 2009 Jun;5(60:330-335.

11. Featherstone JDB, Dental caries: a dynamic disease process. Austr Dent J. 2008, Sep; 53(3):286-291. [PubMed] [CrossRef]

12. Featherstone JDB, The Continuum of Dental Caries - Evidence for a Dynamic Disease Process, J Dent Res. 2004 Jul;83(Suppl 1):C39-42. [PubMed] [CrossRef]

13. Ginty J. Astma medication and caries. Br Dent J. 1997 Feb 8;182(3):88. [PubMed]

14. Gustaffson BE, Quensel CE, Lanke LS, Lundqvist C, Grahnen H, Bonow BE, et al. The Vipeholm dental caries study; the effect of different levels of carbohydrate intake on caries activity in 436 individuals observed for five years, Acta Odontol Scand. 1954 Sep;11(3-4):232-264. [PubMed]

15. Gustaffson BE, The Vipeholm dental caries study: survey of the literature on carbohydrates and dental caries, Acta Odontol Scand. 1954 Sep;11(3-4):207-231. [PubMed]

16. Hyyppa T, Paunio K. Oral health and salivary factors in children with asthma. Proc Finn Dent Soc. 1979; 75(1-2):7-10. [PubMed]

17. Jensen ME, Diet and dental caries. Dent Clin North Am. 1999 Oct;43(4):615-633. [PubMed]

18. Kankaala TM, Virtanen JI, Larmas MA. Timing of first fillings in the primary dentition and permanent first molars of asmathic children. Acta Odontol Scand. 1998 Feb;56(1):20-24. [PubMed]

19. Kargul B, Tanboga I, Ergeneli S, Karakoc F, Dagli E. Inhaler medicament effects on saliva and plaque $\mathrm{pH}$ in asthmatic children. J Clin Pediatr Dent. 1998 Winter;22(2):137-140. [PubMed]

20. Kreth J, Zhu L, Merritt J, Shi W, Qi F. Role of sucrose in the fitness of Streptococcus mutans, Oral Microbiol Immunol. 2008 Jun;23(3): 213-219. [PubMed] [CrossRef]

21. Laurikainen K, Kuusisto P. Comparison of the oral health status and salivary flow rate of asthmatic patients with those of nonastmatic adults-results of a pilot study. Allergy 1998 Mar;53(3): 316-319. [PubMed]

22. Marsh PD. Dental Plaque as a Biofllm: The Significance of $\mathrm{pH}$ in Health and Caries, Compend Contin Educ Dent. 2009 Mar;30(2):76-88, 80, 83-7; quiz 88, 90. [PubMed]

23. Marsh PD. Dental Plaque as a Microbial Biofilm. Caries Res. 2004 May-Jun;38(3):204-211. [PubMed]

24. Marsh PD. Microbial Ecology of Dental Plaque and its Significance in 
Health and Disease. Adv Dent Res. 1994 Jul;8(2):263-271. [PubMed]

25. Marsh PD. Microbiologic aspects of dental plaque and dental caries. Dent Clin North Am. 1999 Oct; 43(4):599-613, v-vi. [PubMed]

26. Marshall TA. Caries prevention in pediatrics: Dietary guidelines. Quintessence Int. 2004 Apr;35(4):332335. [PubMed]

27. McDerra EJ, Pollard MA, Curzon ME. The dental status of asthmatic British school children. Pediatr Dent. 1998 Jul-Aug;20(4):281287. [PubMed[

28. Nederfors T. Xerostomia: prevalence and pharmacotherapy with special reference to beta-Adrenoreceptor antagonists. Swed Dental J Suppl. 1996; 116:1-70. [PubMed]

29. O'Sullivan EA, Curzon MEJ. Drug treatments for asthma may cause erosive tooth damage. BMJ. $1998 \mathrm{Sept}$ 19;317(7161):820. [PubMed] [CrossRef]

30. Paunio P, Rautava P, Helenus H, Alanen P, Sillapaa M. The Finnish Family Competence Study: The Relationship between Caries, Dental Health Habits and General Health in 3Year-Old Finnish Children. Caries Res. 1993; 27(2):154-160. [PubMed]

31. Ryberg M, Moller C, Ericson T. Effect of beta-adrenoreceptor agonists on saliva protein and dental caries in asthmatic children. J Dent Res. 1987 Aug;66(8):1404-1406. [PubMed] [CrossRef]

32. Ryberg M, Moller C, Ericson T. Saliva composition and caries development in asthmatic patients treated with $\beta 2$-adrenoreceptor agonists: a 4- year follow-up study. Scand J Dent Res. 1991 Jun;99(3):212-218. [PubMed]

33. Saunders RH, Hendelman SL. Effects of hyposalivary medications on saliva flow rates and dental caries in adults aged 65 and oider. Spec Care Dentist. 1992 May-Jun;12(3):116. [PubMed]

34. Shashikiran ND, Reddy VV, Raju PK. Effect of antiasthmatic medication on dental disease: dental caries and periodontal disease. $J$ Indian Soc Pedod Prev Dent. 2007 Apr-Jun; 25(2):65-8. [PubMed] [CrossRef]

35. Shulman JD, Taylor SE, Nunn ME. The Association between Asthma and Dental Caries in Children and Adolescents: A Population-Based CaseControl Study. Caries Res. 2001 JulAug;35(4):240-246. [PubMed] [CrossRef]

36. Sissons CH, Anderson SA, Wong L, Coleman MJ, White DC. Microbiota of Plaque Microcosm Biofilms: Effect of Three Times Daily Sucrose Pulses in Different Simulated Oral Environments. Caries Res. 2007; 41(5):413-422. [PubMed] [CrossRef]

37. Sreebny LM, Schwartz SS. A reference guide to drugs and dry mouth2nd edition. Gerodontology. 1997 Jul;14(1):33. [PubMed] [CrossRef]

38. Stensson M, Wendt LK, Koch G, Oldaeus G, Ramberg P, Birkhed D. Oral health in young adults with long-term, controlled asthma. Acta Odontol Scand. 2011 May;69(3):158-64. Epub 2011 Jan 13. [PubMed] [CrossRef]

39. Stensson M, Wendt LK, Koch G, Nilsson M, Oldaeus G, Birkhed D. Oral health in pre-school children with asthma-followed from 3 to 6 years. Int
J Paediatr Dent. 2010 May;20(3):16572. [PubMed] [CrossRef]

40. Stensson M, Wendt LK, Koch G, Oldaeus G, Birkhed D. Oral health in preschool children with asthma. Int $J$ Paediatr Dent. 2008 Jul;18(4):243-50. Epub 2008 May 16. [PubMed] [CrossRef]

41. Storhaug K. Caries experience in disabled pre-school children. Acta Odontol Scandin. 1985 Aug; 43(4):241248. [PubMed]

42. van Leeuwen A, Zwaan CL. Do inhalation medicines have an effect on caries activity? Ned Tijdschr Tandheelkd. 1999 Jul;106(7):279. [Article in Dutch] [PubMed]

43. Wogelius P, Poulsen S, Swrensen HT. Use of asthma-drugs and risk of dental caries among 5 to 7 year old Danish children: a cohort study. Community Dent Health 2004 Sep; 21(3):207-11. [PubMed]

44. Woltgens JHM, Influence of Sugar Consumption, J Ped Dent Care 2008, 13/14, Issue 4/1:14-18

45. Zero DT, Fontana M, MartinezMier EA, Ferreira-Zandona A, Ando M, Gonzalez-Cabezas C, et al. The biology, prevention, diagnosis and treatment of dental caries. J Am Dent Assoc. 2009 Sep;140(Suppl 1):25S-34S. [PubMed]

46. Zero DT. Dental caries process, Dent Clin North Am 1999 Oct;43(4): 635-664. [PubMed]

47. Zhu JF, Hidalgo HA, Holmgreen WC, Redding SW, Hu J, Henry RJ. Dental management of children with asthma. Pediatr Dent. 1996 Sep-Oct; 18(5):363-70. [PubMed]

\section{Corresponding author:}

Dr. Emilia Goshova Karova

Department of Conservative dentistry, Faculty of Dental Medicine, MU - Sofia 1, St. G. Sofiiski Blvd., 1431 Sofia, Bulgaria

e-mail: karova_e@yahoo.com 